\title{
The Effects of Cover Crown, Percentage and Slope Aspect on the Quantitative Distribution of the Alder's Saplings in Forests of North of Iran
}

\author{
Mousavi K. S. A. ${ }^{1, *}$, G. Ali Roshani ${ }^{2}$, S. G. Jalali ${ }^{3}$, A. Shahrdami ${ }^{4}$ \\ ${ }^{1}$ Researcher in Gilan's Agricultural and Natural Resources Research Center, Rasht, Iran \\ ${ }^{2}$ Golestan's Agricultural and Natural Resources Research Center, Gorgan, Iran \\ ${ }^{3}$ Tarbiat Modares University, Noor, Iran \\ ${ }^{4}$ Iranian Organization of Forestry, Rangeland and Watershed Management, Iran
}

\begin{abstract}
Alder (Alnus Subcordata) allocates itself to the 7.6 percent of Iran's northern forests and after the Beech, Hornbeam and Oak, is the fourth commercial tree of Iran. This tree is aborigine of northern parts of Iran and with itself and in a mixed form with the other tree species, forms a various forest community. The Alder is a pioneer species, establishes in an open area of the forest, because it likes more lightness to producing a huge quantity of seeds yearly. It is playing an active role in nitrogen fixation in which can improves soil fertility also. The importance of the Alder is related to its role in regeneration processes of ruined forests and using them for re-plantation. The studied area was a part of Tonekabon's forest, covered with species like hornbeam, The Alder and Maple. In this study, the quantitative situation of the Alder's regeneration in the different cover crowns (30-40, 50-60 and 70-80 per cent), slope percentages $(0-20,30-50$ per cent) and slope direction (Northern, Southern, Eastern \& Western directions) were studied in a factorial experiment using complete randomized block design with four replications. In 72 chosen plots, the quantitative situation and regeneration establishments of the trees having height of more than 1.3 meter or less than 1.3 meter were studied, and the collected data being analyzed using SPSS software. The results showed that, the Alder regeneration in the most humid places (north) and least slope $(0-20 \%)$ consisted of more frequency in comparison with the western and eastern slope directions with more slope (30-50\%). In addition, with decrease in cover crown percentage, the frequencies of the Alder's saplings were also being increased.
\end{abstract}

Keywords The Alder, Alnus Subcordata, Regeneration, Cover Crown And Slope Direction

\section{Introduction}

Forest regeneration will guarantee its future. To make a guarantee to produce wood and the other forest's services continuously, we need a permanent and suitable productivity in forests. Therefore, having enough knowledge and study about forestry characteristics about different species of trees in order to guarantee forest's natural regeneration is essential. The Alder is a type of species with a great importance in northern forests. The study aims was to review the effects of different factors such as, the cover crown intensity, slope direction and degree, with regard to productivity situation of this species in one of the northern forest (two channel series from Liresar of Tonekabon plot). Sagheb (1995) reported that in cavity with size of $0.1-0.4$ hectare, the light intensity has a negative effect on sapling quality. Abrams (1998) in his study upon Maple reported that, these species prefer shadow,

* Corresponding author:

abdy_mo@yahoo.com (Mousavi K. S. A.)

Published online at http://journal.sapub.org/re

Copyright (C) 2012 Scientific \& Academic Publishing. All Rights Reserved a mild cover crown and the floor have a suitable number of regeneration. Jalali (2006) reported that the Beech productivity in north and north-west slope direction and in valleys with less slopes is more. The research of Gorgi (1998) showed that, the productivity rate of the Alder species depends on soil properties, topography, humidity, soil depth, its fertility and effective environmental factors. Mousavi (2000) reported that, unlike the effects of slope percentage, the size of cavity surface has a positive effect on Beech saplings and its abundant average and sapling's collar diameter also. Seifolahian (2000) reported that, the cavity diameter of natural life regeneration for an old Beech forest in Bolgaria in high slope, lightened slope should be 10-15 meter, and in lightened slope with slope, less than $20 \%$ should be more than 20 meter. Seif Elahiyan(2000) quoted from Upensky announced that cover crown rate, forest light and cavity surface size of cover crowns are the important factors for forest regeneration so the cavity size depends on tree species, growth plant, and the slope. Yammoto (1988) quoted from Walecj and Ricklefs announced that inside the cavity especially in large surface cavity, there are more varieties in tree species productivity. Lust (1994), in life regeneration study 
of mixed forests resulted that cover crown rate in regulation and forest's mixture and height growth of life regeneration have important role and suitable site of cavity depends on the species and slope. Guo et al. (2001) determined through their review that, different light regimes in forest from full light to shadow have a significant effect on oak productivity revival. Also, Stringer (2002) announced that acorn production in cover crown with less accumulation is more and this situation increases Oak production potential. Ross Tryon, Carvel, et al. (1986) concluded that Oak production in case of high floor and accumulated under floor is not successful, because, low light is not suitable for Oak production. Yang Ham (1996) in his review showed relationships between Bamboo production and topography situations and resulted that the high accumulated bamboo under tree floor, prevent growth and development of forest's species, especially productivity and growth of prevailing tree's species. Bamboo easily develops in mild slope with height between 100 to 800 meter, and it is limited in valleys and crests. Sasa (a kind of bamboo) has not been affected by area slope, but it seems that in southern slopes it is better than northern slopes. Tabari et al. (1998) saw in their study, close and positive relationships between permanence rate and Ash tree growth with increase of cover crown cavity surface.

\section{Methods}

The study area was located in Tonekabon's forests, in Mazandaran province and in northern parts of Iran (with $39^{\circ}$ $36 \mathrm{~N}$ and $50^{\circ} 51^{\circ} \mathrm{E}$ as its latitude and longitude, respectively). The experimental plots were located at $650-1150 \mathrm{~m}$ above the sea level with $1300 \mathrm{~mm}$ as the average annual rainfall. Rainfall distribution is related to the seasons and based on the information from long term data, about $35-45 \%$ of the rainfall will occurred in autumn season (from September to November), $18-35 \%$ in winter season (December to February), and having the rest of the rainfall (10-20\%) in summer season (June to August). The region has relatively mild temperature and the difference between maximum and minimum temperature during a year is about $30^{\circ} \mathrm{C}$. The average of minimum temperature from December to March is below zero. The parent materials of the soils are alluvial sediments remaining from 4th period of Geochronology, which have a low slope degree without any gravel. The forests covered with Horn Bean, the Alder, Maple and Beech.

The first step to study the regeneration processes and the effects of factors like; cover crown, percentage and direction of slope is surveying of the area under investigation. In our study, we tried to neutralize the effects of some natural factors such as elevation from the sea level and soil characteristics by choosing the plots having the same soil and with a maximum elevation difference of $200 \mathrm{~m}$. Three different cover crowns (30-40, 50-60 and 70-80 per cent), two slope percentages $(0-20,30-50$ per cent $)$ and four slope direction (northern, southern, eastern \& western directions) were studied in a factorial experiment using complete randomized block design with four replications. Finally, 174 cavities were determined in which 72 plots with the size of $2 \mathrm{~m} 2$ were chosen randomly and the collected data were analyzed using SPSS software.

\section{Results}

\subsection{The Effect of Cover Crown on Sapling with Height Less Than $1.3 \mathrm{~m}$}

The comparison of the Alder saplings frequency showed that sapling frequency in 30-40\% cover crown has a significant difference, with $95 \%$ of reliability, with cover crown of $50-60 \%$. According to Table 1 , the frequency of the Alder's saplings with height less than 1.3 in $30-40 \%$ of cover crown is more than cover crown of both 50-60 and 70-80\%. Also the frequency of the above mentioned saplings in crown cover of $70-80 \%$ is more than cover crown of $50-60 \%$.

Table1. Frequency and percentages of the Alder's sapling with different height in different crown cover.

\begin{tabular}{|c|c|c|c|c|}
\hline $\begin{array}{c}\text { percentage } \\
\text { of cover } \\
\text { crown }\end{array}$ & $\begin{array}{c}\text { Percentage } \\
\text { and } \\
\text { frequency }\end{array}$ & $\begin{array}{c}\text { sapling } \\
\text { height }>1.3 \mathrm{~m}\end{array}$ & $\begin{array}{c}\text { sapling } \\
\text { height }<1.3 \mathrm{~m}\end{array}$ & total \\
\hline \multirow{2}{*}{$30-40 \%$} & number & $187^{\mathrm{a}}$ & $75^{\mathrm{a}}$ & 262 \\
\cline { 2 - 5 } & percentage & 71.3 & 28.70 & 100 \\
\hline \multirow{2}{*}{$50-60 \%$} & number & $54^{\mathrm{b}}$ & $0^{\mathrm{c}}$ & 52 \\
\cline { 2 - 5 } & percentage & 100 & 0 & 100 \\
\hline $70-80 \%$ & number & $67^{\mathrm{b}}$ & $8^{\mathrm{b}}$ & 75 \\
\cline { 2 - 5 } & percentage & 89.3 & 10.7 & 100 \\
\hline
\end{tabular}

\subsection{The effect of Cover Crown on Saplings with Height More Than $1.3 \mathrm{~m}$}

The comparison of the Alder's saplings frequency in cover crown of $30-40 \%$ showed a significant difference, with $95 \%$ reliability, with its frequency in cover crown of both 50- 60 and $70-80 \%$. But the frequency of the above mentioned saplings in cover crown 50- 60 and 70- 80\% did not showed any significant differences. According to Figure 1, the frequency of the Alder's saplings with height more than $1.3 \mathrm{~m}$ in cover crown of $30-40 \%$ is more than cover crown of 5060 and $70-80 \%$.

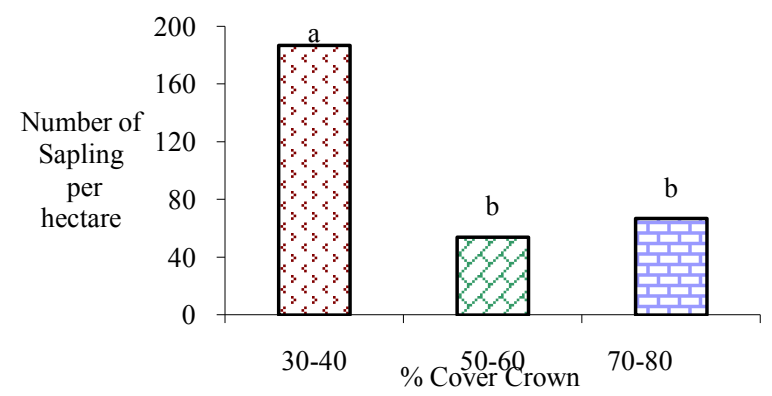

Figure 1. Frequency of the Alder's saplings (height $>1.3 \mathrm{~m}$ ) in different cover crown

\subsection{The Effect of Different Slope Direction on Saplings with Height Less Than $1.3 \mathrm{~m}$}

Comparison of the frequency of the Alder's saplings 
showed that the sapling frequency in Northern direction was different those in Eastern and Western direction. Also sapling frequency in Eastern direction has a significant difference, with $95 \%$ of reliability, with Western direction. According to Figure 2, the frequency of the Alder's sapling with height less than $1.3 \mathrm{~m}$ in Northern direction is more than Eastern and Western direction. Also the frequency of above mentioned saplings in Eastern direction is more than Western direction.

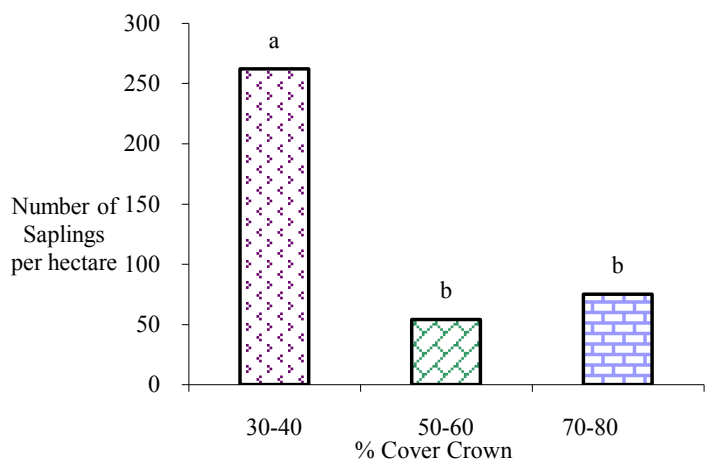

Figure 2. Frequency of the Alder's saplings (height $<1.3 \mathrm{~m}$ ) at different slope directions

\subsection{The Effect of Different Slope Direction on Saplings with Height More Than 1.3m}

Comparison of the frequency of the Alder's saplings showed that sapling frequency in Northern direction has a significant difference, with $95 \%$ of reliability, with sapling frequency in Eastern and Western directions. But, sapling frequency in Eastern direction has not any significant differences with Eastern direction. According to Table 2 the Alder's saplings with height more than $1.3 \mathrm{~m}$ in Northern direction were more than Eastern and Western directions.

Table2. Availability of the Alder's saplings (height $>1.3 \mathrm{~m}$ ) through different directions

\begin{tabular}{|c|c|c|c|c|}
\hline $\begin{array}{c}\text { Slope } \\
\text { direction }\end{array}$ & $\begin{array}{c}\text { Percentage } \\
\text { and frequency }\end{array}$ & $\begin{array}{c}\text { sapling } \\
\text { height }>1.3 \mathrm{~m}\end{array}$ & $\begin{array}{c}\text { Sapling } \\
\text { height }<1.3 \mathrm{~m}\end{array}$ & total \\
\hline \multirow{2}{*}{ Northern } & Number & $204 \mathrm{a}$ & $75 \mathrm{a}$ & 279 \\
\cline { 2 - 5 } & Percentage & $1 / 73$ & 26.90 & 100 \\
\hline \multirow{2}{*}{ Eastern } & Number & $50 \mathrm{~b}$ & $8 \mathrm{~b}$ & 58 \\
\cline { 2 - 5 } & Percentage & $2 / 86$ & 13.8 & 100 \\
\hline \multirow{2}{*}{ Western } & Number & $54 \mathrm{~b}$ & $0 \mathrm{c}$ & 54 \\
\cline { 2 - 5 } & Percentage & 100 & 0 & 100 \\
\hline
\end{tabular}

\subsection{The Effect of Slope Percentage on Saplings with Height Less Than 1.3m}

Comparison of the Alder's saplings frequency showed that, with $95 \%$ of reliability, the sapling frequency at slope of $0-20 \%$ has a significant difference with its frequency in slope of $30-50 \%$. According to Table 3 the frequency of the Alder's saplings with height less than $1.3 \mathrm{~m}$ in mild slope $(0-20 \%)$ was more than high slope (30-50\%).

\subsection{The Effect of Slope Percentage on Saplings with Height More Than 1.3 M}

Comparison of the Alder's sapling frequency showed that, with $95 \%$ of reliability, the frequency of sapling slope
$0-20 \%$ has not any significant differences with sapling frequency in slope $30-50 \%$.

Table 3. Availability of the Alder's saplings with different height in different slope percentage

\begin{tabular}{|c|c|c|c|c|}
\hline $\begin{array}{c}\text { Slope } \\
\text { percentage }\end{array}$ & $\begin{array}{c}\text { Percentage } \\
\text { and } \\
\text { frequency }\end{array}$ & $\begin{array}{c}\text { Sapling } \\
\text { height } \\
>1.3 \mathrm{~m}\end{array}$ & $\begin{array}{c}\text { sapling } \\
\text { height } \\
<1.3 \mathrm{~m}\end{array}$ & total \\
\hline \multirow{2}{*}{$0-20$} & Number & 186 & 55 & 241 \\
\cline { 2 - 5 } & percentage & 77.1 & 22.90 & 100 \\
\hline \multirow{2}{*}{$30-50$} & Number & 194 & 0 & 194 \\
\cline { 2 - 5 } & percentage & 100 & 0 & 100 \\
\hline
\end{tabular}

\section{Discussions and Conclusions}

As it is clear from the results, there is an interesting increases in Alder's regeneration at cover crown of 30-40 \% in compare with the two others cover crown. It seems that, it was because of two main reasons. Firstly, in cover crown of $30-40 \%$ exploitation activities and harvest centralization was more then more soil disturbance has been occurred. Therefore, the Alder's saplings frequency in compare with two other studied cover crown being drastically increased. Secondly, because of high harvesting pressure on Alder the climax being changed and it became the abundant tree in those areas. Smith (1992) reported that the Oak productivity endures shadow, but it can not be alive in closed cover crown. Carvell and Tryon (1961) and Ross et al. (1986) showed that the Oak productivity is not successful, when the over floor and under floor is condensed, because low light is not suitable for its productivity. Shahnavazi (2000) in his study on different species noted to this point that with increasing cavity surface, there was a decrease in all sapling number in surface unit, but the sapling height, with increased surface in cavity hole, increased. The results indicate the fact that the Alder regeneration in northern direction is more than eastern and western direction (Figure 2 and Table 2). This research also showed that the frequency of the Alder's regeneration with height less than $1.3 \mathrm{~m}$ in mild slope $(0-20 \%)$ is more than high slope $(30-50 \%)$. The Alder is a tree which likes more moisture in its root zone. The higher the slope leading to intensive drainage and least soil moisture and therefore the Alder's productivity encountered problems. In addition, Gorgi Bahri (1998) reported that the ground slope and fertility are the most important environmental factors affecting the Alder's productivity. In different cover crown, slope percentage and slope direction there are great difference between frequency of the Alder's saplings having the height more than $1.3 \mathrm{~m}$ and the height less than $1.3 \mathrm{~m}$.

It seems that, the Alder's species having the power of regeneration and localization only in early years and has not any continuation in its regeneration in elder stage. Lust (1994) studied about mixed forest regeneration and reported that, the level of cover crown has an important role on regulating the condensation of forest complex and the height growth and suitable size of the cavity depends on species and slope. Guo et al. (2001), reported that, different light regimes in 
forest from full light to shadow has a significant effect on Oak regeneration and its localization.

\section{REFERENCES}

[1] Abrams M.D. (1998). The red maple paradox. Biosciences. 48(5): 355-364 pp

[2] Carvell, K.L. and Tryon, E.H. (1961) .The effect of environmental factors on the abundance of oak regeneration beneath mature oak stand. Forest Science. (7): 98-105

[3] Gorgi Bahri, Y. (1998). The country Alder wood planting and production. Mazandaran's Natural Resources Research Center. Noshahr, Iran.pp.9

[4] Guo, Y.,Shelton, MG.and Lockhart, B.R.2001. Effects light regimes on the growth of Cherrbark Oak seedlings. Forest Science. 47 (2): $270-277$

[5] Lust, N. (1994), Regeneration patterns and Problems in Mixed Forest Laboratory of Forestry - University of GHENT, Silva Gandavensis , No: 21

[6] Moosavi, R. (2000). The qualitative and quantitative study of productivity cavities. The M.Sc. thesis, Noor Natural Resources and Sea life Science Colleges.pp.70

[7] Parrotta, J. A. (1999 ). Productivity, nutrient cycling, and succession in single- and mixed- species plantations of Casuarina equisetifolia, Eucalyptus robusta and Leucaena leucocephala in Puerto Rico. Forest Ecology and Management, 124: $45-77$

[8] Sagheb Talebi, K. (1995). Study of some characteristics of young beeches in the regeneration gaps irregular shelterwood system. Genetics and silviculture of beech Denmark, Forkingsserien Nr.11 : $105-111$

[9] Seif Elahiyan, M. (2000). The study of size and area of cover crown cavity in mixed forest. Forestry Technical Office

[10] Seif Elahiyan, M. (2000). The study of Natural Regeneration of old forests. Forestry Technical Office .pp.1

[11] Smith, D.W.1993. Oak regeneration: The scope of the problem. In: Loftis, D., McGee, C., eds., Oak regeneration: Serious problems, practical recommendations. 8-10 Sept. 1992, Knoxville, TN. USDA Forest Service Gen. Tech. Rep. SE-84: $40-52$

[12] Tabari, m. Lust, N.and Neiynck, J.(1998) .Effect of light and humus on survival and height growth of ash ( Fraxinus excelsior L.) seedlings . Silva Gandavensis, 63: 36- 50

[13] Wradle, P. (1959). The regeneration of Fraxinus excelsior in woods with a field layer of mercurialis perennis - J.Ecol.47: $483-497$

[14] Yamamoto, S. (1998). Gap disturbance regimes in different forest types of Japan .Journal of Sustainable Forestry. Vol.6. No.3/4: $223-235 \mathrm{pp}$ 